\title{
Cytogenetical and morphological features reveal significant differences among Venezuelan and Brazilian samples of Mugil curema (Teleostei: Mugilidae)
}

\author{
Mauro Nirchio*, Roger Cipriano**, \\ Margarete Cestari**, and Alberto Fenocchio***
}

Karyotype of $M$. curema from the Gulf of Mexico and Brazil have been reported as possessing chromosome complement with $2 \mathrm{n}=28$ and $\mathrm{FN}=48$, whereas specimens from Venezuela has been reported as possessing a diploid number $2 \mathrm{n}=24$ and a conserved FN (48). Although at first sight this variation suggests the presence of a chromosomal intraspecific (interpopulational) variability, the possibility that we are dealing with two different species was examined. This work revisit the karyotypes of $M$. curema from Venezuela and Brazil, including new data on C-banding, and NOR localization, and compares morphologic characteristics of samples from both localities. Thus, besides diploid number, the constitutive heterochromatin distribution and NORs location, mark other differences between M. curema Cytotype $1(2 \mathrm{n}=28 ; \mathrm{FN}=48)$ and Cytotype $2(2 \mathrm{n}=24 ; \mathrm{NF}=48)$. Moreover, morphologic comparison revealed differences in the scale counts and pectoral fin rays: 35 scales in the middle body line and 15 pectoral fin rays in specimens possessing the karyotype $2 n=28$, compared with $37-39$ scales in the middle body line and 17 pectoral fin rays in specimens with the karyotype $2 n=24$. These differences lead us to suggest that both cytotypes are not related merely to geographic polytipic variations but could correspond to different species.

Os cariótipos de M. curema do Golfo do México e do Brasil possuem 2n=28 cromossomos e NF=48. Espécimes da Venezuela, entretanto, apresentam um número diplóide de 28 cromossomos e um NF conservado (48). Apesar desta variação sugerir, a princípio, uma variabilidade intraespecífica (interpopulacional), a possibilidade de estarmos perante diferentes espécies foi investigada. O presente trabalho re-analisa os cariótipos de M. curema da Venezuela e do Brasil, incluindo novos dados sobre bandamento C e localização das NORs e compara caracteres merísticos e morfométricos de amostras de ambas as localidades. Assim, junto com o número cromossômico, a heterocromatina constitutiva e a distribuição das NORs trazem outras diferenças entre $M$. curema Citótipo $1(2 \mathrm{n}=48, \mathrm{FN}=48)$ e Citótipo $2(2 \mathrm{n}=48, \mathrm{FN}=48)$. Além disso, as comparações dos caracteres morfológicos revelam diferenças nas contagens, com 35 escamas na linha média do corpo e 15 raios nas nadadeiras peitorais nos espécimes com cariótipo $2 \mathrm{n}=28$, já o cariótipo $2 \mathrm{n}=24$ apresenta 37-39 escamas e 17 raios nas peitorais. Essas diferenças sugerem que ambos citótipos não estão relacionados meramente a variações geográficas politípicas mas que podem corresponder a diferentes espécies.

Key-Words: karyotype, C-band, NOR-banding, meristic and morphometric features, species identification.

\section{Introduction}

White mullet (Mugil curema) is a wide-spread coastal pelagic fish occurring in the Western Atlantic from Massachusetts to southern Brazil (Marin et al., 2003).

Cytogenetic data on Mugil curema have highlighted important differences between specimens from different areas. Indeed specimens from Louisiana, USA, exhibit a chromosome complement with $2 \mathrm{n}=28$ and $\mathrm{FN}=48$ (Le Grande \& Fitzimons, 1976), similar to the one described in a Brazilian population by Cipriano et al. (2002). On the other hand, specimens from Venezuela shows a reduced diploid number, $2 \mathrm{n}=24$ and a conserved $\mathrm{FN}=48$

\footnotetext{
* Escuela de Ciencias Aplicadas del Mar, Universidad de Oriente, Apartado Postal 147-Porlamar, Isla de Margarita, Venezuela. e-mail: nirchio@cantv.net

** Departamento de Genética, Centro Politécnico, Universidade Federal do Paraná, Curitiba, Brazil. e-mail: margaces@ufpr.br

*** Universidad Nacional de Misiones, Argentina. Universidade Estadual de Londrina. e-mail: afenocch@fceqyn.unam.edu.ar
} 
(Nirchio \& Cequea, 1998). Cytogenetic data reported for samples from Venezuela (Caribbean Sea), include conventional (Giemsa) staining (Nirchio \& Cequea, 1998), base-specific fluorochrome staining (Rossi et al., 2004), and Nucleolus Organizer Regions (NORs) localization by Ag-staining (Nirchio et al., 2001), and FISH, as well as the chromosome localization of 5S rDNA and the (TTAGGG) ${ }_{\mathrm{n}}$ telomeric repeats (Rossi et al., 2004), while only the conventional karyotype has been reported for the population from USA and Brazil (Le Grande \& Fitzimons, 1976; Cipriano et al., 2002).

Although at a first sight this variation might indicate the presence of a chromosomal intraspecific (interpopulational) variability, the possibility that we are dealing with two different species should not be discarded. Indeed meristic and morphometric data used to establish taxonomic relationships in mugilids gave rise to a confusing taxonomy due to the conservative external morphology of the family, a problem evidenced by the large synonymy, that includes up to 233 nominal species only 80 of which have been recognized as valid species (Pauly \& Froese, 2004). Moreover, Mugil sp. (formerly gaimardianus, suppressed name by the International Commission on Zoological Nomenclature, ICZN 1787) and M. curema were recently identified as separate species on the basis of their karyotype (Nirchio et al., 2003), which reveals the importance of karyotypic studies in solving taxonomic problems among closely related species.

All these data prompted us to investigate the chromosome complement of specimens of M. curema from Brazil, analyzing the heterochromatin distribution by $\mathrm{C}$-banding and the NORs number and localization by Ag-staining, adding new data on C-banding of specimens from Venezuela. Moreover, we compared meristic and morphometric characteristics of samples from both localities. Thus, this work seeks to contribute to the understanding of whether we are dealing with karyotypic differences between different populations (polytypism) or whether we are dealing with two different species, as originally proposed (Nirchio \& Cequea, 1998).

\section{Materials and Methods}

Specimens of M. curema were collected in coastal waters of the Paranaguá Bay from Paraná State, Brazil $(n=3)$ and near La Restinga Lagoon, Margarita Island, Venezuela $(n=23)$. Samples from Brazil (Fig 1a) and Venezuela (Fig 1b) consist of specimens ranging in total length from 151.0 $270.0 \mathrm{~mm}$. Voucher specimens are deposited in the Genetics and Evolution Laboratory of the Department of Aquaculture, Universidad de Oriente, Margarita Island, Venezuela (Brazil, ECAM: 000179, 000180, 000181; Venezuela, ECAM: 000034, 000035, 000037, 000069, 000070, 000073, 000149, 000153, 000158).

Morphological diagnostic features of $M$. curema were compared for both samples following the keys provided by
Menezes (1983) and Cervigón (1993) for mullets from Brazil and Venezuela respectively.

Chromosome preparations were obtained using the airdrying techniques described by Bertollo et al. (1978). NORs were detected by chromosome impregnation with silver nitrate (Howell \& Black, 1980), and C-bands were obtained according to the method described by Sumner (1972). Mitotic chromosomes were photographed and images digitally processed with ADOBE PHOTOSHOP v. 7.0. This software was also used for constructing the karyogram, with chromosomes organized in decreasing size order. Chromosome morphology followed Levan et al. (1964).

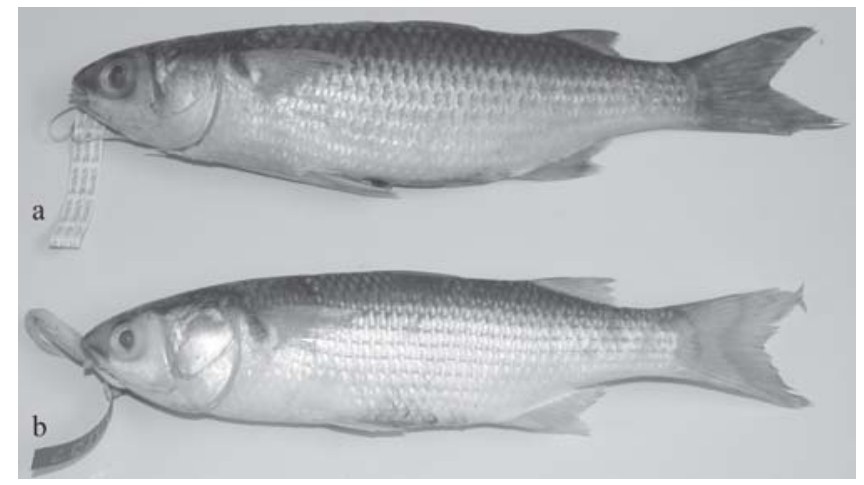

Fig. 1. Specimens of M. curema from (a) Brazil and (b) Venezuela preserved in formalin.

\section{Results and Discussion}

Comparison of diagnostic characteristic employed for identifying M. curema in Brazil (Menezes, 1983) and in Venezuela (Cervigón, 1993) revealed that both our samples shared several key features: widely separated spiny-rayed dorsal fins, with 4 spines ( $1^{\text {st }}$ dorsal fin) and 9 soft-rays $\left(2^{\text {nd }}\right.$ dorsal fin); pelvic fins subabdominal, with 1 spine and 5 branched soft rays; anal fin with 3 spines and 9 soft-rays; ctenoid scales in adults; pectoral axillary scales present, anal fin profusely covered with small scales; small teeth, but visible at first sight, without a clearly curved tip in right angle; adipose eyelid present and a dark blotch visible at the base of the pectoral fin. Differences between both samples concern the scale counts and the number of pectoral fin rays: Indeed, 35 scales in the middle body line and 15 pectoral fin rays have been counted in specimens from Brazil, whereas 37-39 scales on the middle body line and 17 pectoral fin rays have been counted in specimens from Venezuela.

Based on the chromosome numbers, samples can be identified and classified as Cytotype 1 and Cytotype 2. Cytotype 1 , consisting of $2 \mathrm{n}=28,20 \mathrm{M}+4 \mathrm{ST}+4 \mathrm{~A}$, was detected in all individuals from Brazil (fig. $2 \mathrm{~A}$ ) and corresponds to the karyotype originally described for the species by Le Grande \& Fitzsimons (1976). Cytotype 2 corresponds to specimens from Venezuela (Fig. 2 d) and consists of $2 n=24,22 M+2 S M$. 


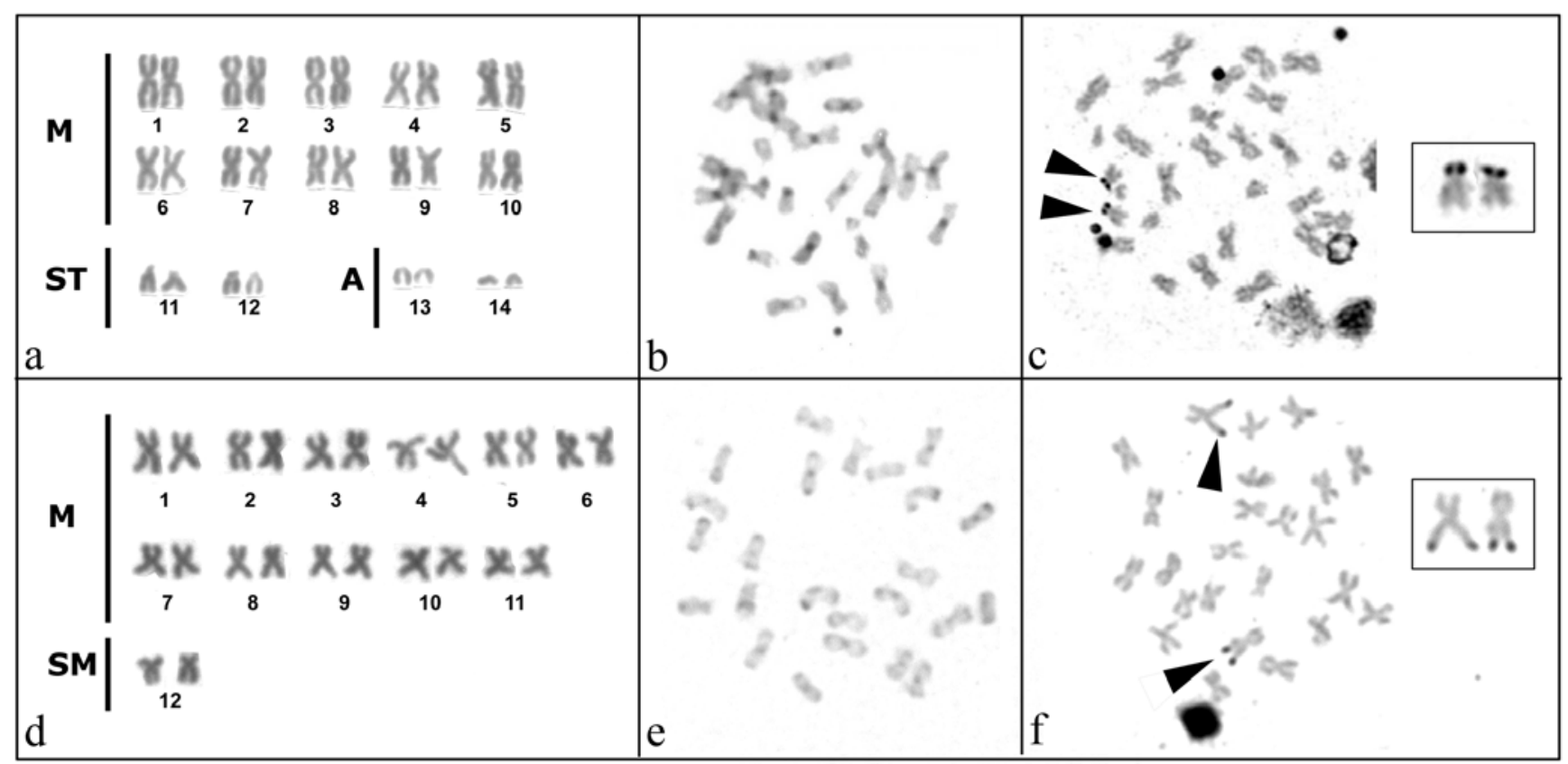

Fig. 2. Karyotypes of Mugil curema and metaphase plates after C-banding (b and d) and Ag-NOR (c and f) in samples from Brazil (a-c) and Venezuela (d-f). An enlargement of the NOR-carrying chromosome pair is shown in the inset in $\mathrm{c}$ and $\mathrm{f}$.

After C-banding specimens with the Cytotype 1 (Fig. 2 b) display only pericentromeric heterochromatin whereas specimens with the Cytotype 2 (Fig. 2 e) show the heterochromatin distribution at pericentromeric and telomeric regions of all chromosomes with some chromosomes displaying intercalary heterochromatic blocks, some being more conspicuous than others.

The specimens with the Cytotype 1, have Ag-NORs located on the telomeric region of the short arm of the subtelocentric chromosome pair $\mathrm{N}^{\circ} 11$ (Fig. 2 c). The specimens with the Cytotype 2 show the NORs located on the telomeric region of the long arm of the metacentric chromosome pair $\mathrm{N}^{\circ} 1$ (Fig. $2 \mathrm{f}$ ), as previously described (Nirchio et al., 2001; Rossi et al., 2004).

The terminal position of NORs on the largest pair of acrocentric chromosomes has been suggested to be the plesiomorphic condition in the genus Mugil, a feature shared by $M$. cephalus (Rossi et al., 1996), M. platanus (Jordão et al., 1992) and M. liza (Nirchio et al., 2001; Rossi et al., 2004), but not by $M$. trichodon, which possesses the only interstitial NORs observed in Mugilidae (Nirchio et al., 2004). Rossi et al. (2004) have proposed that the NOR pattern of of $M$. curema from Venezuela (Cytotype 2) would reflect the involvement of the largest ancestral NOR-bearing acrocentric chromosome in the centric fusion that produced the metacentric pair number 1 in the species. On the other hand, the NOR localization in Cytotype 1 of $M$. curema from Brazil, on the short arm of one subtelocentric pair, might have arisen from a pericentric inversion or by a reciprocal translocation from the ancestral acrocentric chromosome.

The classical morphological species concept, widely accepted and still pertinent today, takes into account that members of a species are individuals that look similar to one another. Accordingly, could the differences in meristic and morphometric characters be great enough to suggest the existence of two different species?. By comparing meristic and morphometric characteristics, differences concerning the scale counts in the middle body line and the pectoral fin rays were observed between samples from both localities. On the other hand, the biological species concept, establishes that two individuals belong in the same species if their respective gametes can join in amphimixis under natural conditions to produce fertile offspring. If these two morphs definitely belong to the same species, we should expect to observe individuals in the wild with an intermediate karyotype between Cytotype 1 and Cytotype 2 (i.e: $2 \mathrm{n}=26$ ). In spite of having analyzed in our laboratory over 150 samples of $M$. curema since 1998, we have not been able to unearth any individual with this intermediate karyotype and no report supporting this possibility appears to have been published so far. So, the cytogenetic and morphologic differences lead us to suggest that the two cytotypes are not merely related to geographic polytipic variations but, indeed, will be consistent with different species.

\section{Acknowledgements}

The authors are grateful for the valuable comments and suggestions on the manuscript given by Luciana Sola and Anna Rita Rossi (Department of Animal and Human Biology, University of Rome I “La Sapienza” Rome, Italy). This work was supported by research grants from Consejo de Investigación, Universídad del Oriente. 


\section{Literatured Cited}

Bertollo, L. A. C., C. S. Takahashi \& O. Moreira-Filho. 1978. Cytotaxonomic considerations on Hoplias lacerdae (Pisces, Erytrinidae). Brazilian Journal of Genetics, 1(2):103-120.

Cervigón, F. 1993. Los peces marinos de Venezuela. Fundación Científica Los Roques. Vol. II. 2da Edición. Caracas, Venezuela.

Cipriano, R. R., M. M. Cestari \& A. S. Fenocchio A. S. 2002. Levantamento citogenético de peixes marinhos do litoral do Paraná. IX Simposio de Citogenética e Genética de Peixes. Maringa, Brazil.

Froese, R. \& D. Pauly (eds). 2004. FishBase. World Wide Web electronic publication. www.fishbase.org, version (04/ 2004).

Howell, W. M. \& D. A. Black. 1980. Controlled silver-staining of nucleolus organizer regions with a protective colloidal developer: a 1-step method. Experientia, 36:1014-1015.

ICZN (1994) **Opinion 1787** Mugil curema and M. liza Valenciennes in Cuvier \& Valenciennes, 1836 (Osteichthyes, Perciformes): species names conserved. Bulletin of Zoological Nomenclature, 51:286-287

Jordão, L. C., C. Oliveira, F. Foresti \& H. Godinho. 1992. Caracterização citogenética da tainha, Mugil platanus (Pisces, Mugilidae). Boletim do Instituto de Pesca, 19:6366

Le Grande, W. H. \& J. M. Fitzsimons. 1976. Karyology of the mullets Mugil curema and Mugil cephalus (Perciformes: Mugilidae) from Louisiana. Copeia, 1976(2):388-391.

Levan, A., A. Fredga. \& A. Sandburg. 1964. Nomenclature for centromeric position on chromosomes. Hereditas 52:201-220.

Marín, B. J., A. Quintero, D. Bussière \& J. J. Dodson. 2003. Reproduction and recruitment of white mullet (Mugil curema) to a tropical lagoon (Margarita Island, Venezuela) as revealed by otolith microstructure. Fishery Bulletin, 101:809.821
Menezes, N. A. 1983. Guia prático para conhecimento e identificaçao das tainhas e paratis (Pisces, Mugilidae) do Litoral Brasileiro. Revista Brasileira de Zoologia, 2(1):1-12

Nirchio, M. \& H. Cequea. 1998. Karyology of Mugil liza and M. curema from Venezuela. Boletín de Investigaciones Marinas y Costeras, 27:45-50.

Nirchio, M., D. González \& J. E. Pérez. 2001. Estudio citogenético de Mugil curema y M. liza (Pisces: Mugilidae): Regiones organizadoras del nucleolo. Boletín del Instituto Oceanográfico de Venezuela, 40:3-7.

Nirchio, M., E. Ron \& A. R. Rossi. (in press). Karyological characterization of Mugil trichodon Poey, 1876 (Pisces: Mugilidae). Scientia Marina, 2004.

Nirchio, M., F. Cervigón, J. I. Rebelo Porto, J. E. Pérez, J. A. Gómez \& J. Villalaz. 2003. Karyotype supporting Mugil curema Valenciennes, 1836 and Mugil gaimardianus Desmarest, 1831 (Mugilidae: Teleostei) as two valid nominal species. Scientia Marina, 67:113-115.

Rossi, A. R., D. Crosetti, E. Gornung \& L. Sola 1996. Cytogenetic analysis of global populations of $\mathrm{Mugil}$ cephalus (striped mullet) by different staining techniques and fluorescent in situ hybridization. Heredity, 76:77-82

Rossi, A. R., E. Gornung, L. Sola \& M. Nirchio. (in press). Chromosomal evolution in Mugilidae (Pisces, Mugiliformes): comparative molecular cytogenetic analysis of two congeneric species, Mugil curema and $M$. liza, characterized by significant karyotype diversity. Genetica, 2004

Sumner, A. T. 1972. A simple technique for demonstrating centromeric heterocromatin. Experimental Cell Research, 75:304-306.

White M. J. D. 1973. Animal Cytology and Evolution. Cambridge University Press, Cambridge, 961p.

Received November 2004 Accepted December 2004 